\title{
The Path to Realize Ideological and Political Full Coverage within Curriculum in Science and Engineering Universities
}

\author{
Peng Zhang ${ }^{1, a}$, Long Lin ${ }^{2}$ \\ ${ }^{1,2}$ School of Humanities and Social Sciences, Anhui University of Science \& Technology, Anhui 232001 \\ aEmail: zhangpeng666521@163.com
}

\begin{abstract}
This article will introduce in detail the importance of ideological and political full coverage within curriculum in science and engineering universities and the ideological and political elements within the colleges and universities. Through professional research and investigation, we will accurately find out the effective path to achieve ideological and political full coverage within curriculum, such as confirming the emphasis of ideological and political construction, optimizing the curriculum's ideological and political teaching system, integrating with professional courses, strengthening the curriculum's ideological and political construction, improving teachers' ideological and political standards, and establishing curriculum's ideological and political evaluation systems, so as to comprehensively enhance the learning level of university students.
\end{abstract}

Keywords: science and engineering universities, ideological and political full coverage within curriculum, teaching system, craftsmanship spirit.

\section{INTRODUCTION}

During the curriculum's ideological and political construction, teachers and managers of science and engineering universities need to carefully understand the essential meaning of the idea, and improving this idea and combining it with college professional courses can effectively realize their ideological and political full coverage within curriculum.

\section{THE HE IMPORTANCE OF IMPLEMENTING IDEOLOGICAL AND POLITICAL FULL COVERAGE WITHIN CURRICULUM IN SCIENCE AND ENGINEERING UNIVERSITIES}

\subsection{INTEGRATING WITH THE DEVELOPMENT OF THE CURRENT ERA}

Ideological and political idea within curriculum is not a separate subject but a kind of ideological and moral idea. Under the current multiple ideas of informationization and globalization, there is more obvious diversity trend, with ideological and cultural blending and conflicts at home and abroad, which is constantly changing with the time.
Some wrong thoughts conceal deeply, which will intensify ideological and thinking confrontation while misleading young people. In terms of culture, the emergence of major changes in the world means the turbulence of exchanges among various ideologies, cultures and civilizations, and there have also been some clashes of civilizations. Under the current background, the science and engineering universities are responsible for the historical mission of building the country. The thinking of their own students has become more important. The main channel for carrying out ideological and political education is the ideological and political courses, but the courses alone hardly satisfy the school's actual requirements for students under the current situation. Therefore, it is necessary to use the advanced ideas in the ideological and political courses to timely manage the ideological cognition of all students, combining efficiently with the ideological and political courses, to effectively enhance the management of students' thoughts, scientifically responding to the complex battles in current ideological ideas. therefore, the ideological and political full coverage within curriculum can complete the integration with the development of the current era. 


\subsection{SPECIFIC REQUIREMENTS FOR THE CONSTRUCTION OF SCIENCE AND ENGINEERING MAJORS}

In the history of the past three industrial revolutions, many technological privileges were monopolized by the West. In other words, previous industrial revolutions showed the progress of the West. Whether it is a scientific revolution or an ideological revolution, its roots are the industrial revolution, and a strong industrial management standard can effectively enhance the productivity of society. From the perspective of science and technology, the current era is the development era of new industrial technology and information technology, and the development of science and technology will affect the development level of the entire country ${ }^{[1]}$. In the current construction of science and engineering universities in China, the national government has also put forward appropriate technical requirements and standards for relevant students. If we want to effectively enhance the national science and technology's construction, students in science and technology universities need to gradually improve their own science and technology standards. In the process of learning related science and technology, it is also more important to have good ideological and moral cognition. College teachers should use the good ideas of ideological and political courses into daily teaching to gradually improve the ideological ideas of their students and make them more willing to serve the country, thus, making our country the vanguard in the construction of new engineering.

\section{IDEOLOGICAL AND POLITICAL ELEMENTS IN SCIENCE AND ENGINEERING UNIVERSITIES}

\subsection{CRAFTSMANSHIP SPIRIT}

Among the specific teaching in science and engineering universities, teachers should not only teach students a large amount of basic knowledge, but also promote the relevant craftsmanship spirit in a timely manner. Specifically, the craftsmanship spirit represents the integration of related skills and practical spirit, and its essence represents related professionalism, such as innovation, focus, refining and dedication. In the current rapid development of the national economy, whether it is created in China or made in China, it is necessary to give play to the spirit of craftsmanship, and every college student must have certain professional ethics and craftsmanship when taking a job. During the lecture giving period, the teacher should highly integrate the craftsmanship spirit with the professional knowledge, analyze the professional spirit of the corresponding vocation according to the specific and industrial characteristics of the profession, and enhance the students' passion in the job using the propaganda in daily life. For multi-processing engineering courses, it has strong practicality. Teachers need to help students exercise their professional spirit in daily teaching, and ingeniously integrate excellence, innovative thinking and professional knowledge into science and engineering courses, so that students become compound talents with morality, intelligence, physical education, aesthetics and diligence.

\subsection{FEELINGS OF PATRIOTISM}

The Chinese spirit is mostly manifested in selfconfidence but not complacency. During the teaching of science and engineering courses, teachers should also let students understand that when China suffers from difficulties, it has strong self-confidence, so that students can consciously shoulder the responsibility of national rejuvenation. In the specific teaching content, teachers should emphasize the idea that "everyone is responsible for the rise and fall of the world," and gradually enhance the students' sense of national mission and responsibility. In the current science and engineering courses, teachers should gradually improve their rational understanding on the basis of introducing cutting-edge science and technology, to make them aware of the status quo that some technologies in our country lag behind some developed countries, so as to enhance the effect of their patriotic education.

\subsection{NATIONAL CONFIDENCE}

In most science and engineering courses, many of the technologies introduced are foreign leading. Some of the students will develop a stereotype of China's weaker technological level. In order to promote the national confidence of college students, teachers need to integrate ideological and political idea into this type of courses. Generally speaking, China's confidence includes cultural confidence, system confidence, road confidence, and theoretical confidence. During the actual teaching, teachers should effectively combine China's achievements with curriculum content, which can not only enrich students' knowledge of science and engineering, but also help students establish national confidence, enhance their national pride, and their sense of identity with characteristic socialist culture, systems, roads and theories ${ }^{[2]}$.

\section{AN EFFECTIVE PATH FOR SCIENCE AND ENGINEERING UNIVERSITIES TO DEVELOP IDEOLOGICAL AND POLITICAL FULL COVERAGE WITHIN CURRICULUM}

In December 2016, Beijing held an ideological and political conference for colleges and universities across the country. In the conference, General Secretary Xi Jinping proposed the perspective of using classroom as channels to improve ideological and political theory. For science and engineering curriculum, the efficient combination of 
the courses and the ideological and political theory can timely improve the students' fundamental values including world views, values of worth and life on the basis of learning more professional knowledge, and then colleges and universities can adopt appropriate measures to design teaching methods with ideological and political full coverage within curriculum.

\subsection{CONFIRMING THE EMPHASIS OF CURRICULUM'S IDEOLOGICAL AND POLITICAL CONSTRUCTION}

During the ideological and political full coverage within curriculum in science and engineering colleges and universities, the teachers need to clarify the emphasis of ideological and political idea within curriculum. Specifically, in the current ideological and political idea within curriculum, its main development goal is to cultivate more high-quality talents, which means that the basic ability of talent cultivating is the core point of its development. At present, many universities are to achieve such goals. In the teaching of the ideological and political idea within curriculum, teachers should use a number of examples to strengthen the students' beliefs and ideals based on the content of the courses, regarding the patriotism and the love for our Party as the main line of the teaching content, improving the content supply of ideological and political courses through political identification.

Specifically, the ideological content of characteristic socialism is placed in relevant textbooks, and this type of teaching content is used to continuously fill the minds of students when teachers carry out the daily teaching of ideological and political idea within curriculum. In daily teaching and life, teachers should use a variety of valuable behaviors to practice and cultivate the core values of socialism, and use this idea to promote and popularize China's excellent traditional cultures to students. In the process of implementing the ideological and political idea within curriculum, teachers should continue to improve the awareness of the rule of law of university students, using a variety of practical cases to implement the constitution-based rule of law education, and multiple ideological updates to improve the professional ethics and ideals of students and to promote the formation of their comprehensive quality. In addition, in most science and engineering universities, students will develop more rational thinking in their daily study and life, while ideological and political idea within curriculum are perceptual thinking. Therefore, it is more important to implement ideological and political idea within curriculum in such schools. After the improvement of this type of ideas, the students will make greater progress for their ideological cognition, and their professional quality and ethics will be improved.

\subsection{OPTIMIZING THE CURRICULUM'S IDEOLOGICAL AND POLITICAL TEACHING SYSTEM}

During the teaching ideological and political idea within curriculum, teachers of science and engineering universities should also optimize the teaching system in a timely manner. First of all, before designing the curriculum's ideological and political teaching system, designers need to clarify the advantages and characteristics of such majors or disciplines, carry out indepth research on the specific education goals of each major, to show the spiritual connotation and ideological value of the professional knowledge. Teachers should use the ideological and political idea within curriculum to expand the human concern, depth and breadth of relevant professional knowledge in a timely manner, and use the historical, cultural, international, national, industrial and professional perspectives within the curriculum to enhance the humanity and knowledge of the curriculum, and to actively improve openness, timeliness and leadership ${ }^{[3]}$. Secondly, in the teaching of professional courses, teachers should pay attention to the unity of knowledge and action in a timely manner, that is, the combination of thought and action, to effectively improve students' practical ability and innovative spirit, so that they can solve multiple problems on their own in the learning process. Finally, teachers should also put the ideological and political idea within curriculum on a number of innovative activities, that is, while teaching such ideas, they should guide students to "be creative and brave" so that they can learn more practical knowledge through individual experience, effectively enhance their entrepreneurial ability, creative consciousness and innovative spirit, and gradually hone their will and quality in daily practice.

\subsection{INTEGRATING WITH THE PROFESSIONAL COURSES}

First, although most of the courses in science and engineering universities are scientific and engineering courses, there are still many basic contents such as law, management and economics. Specifically, when teachers teach such courses, they can incorporate Marxism at the right time, using the theory to construct a suitable discourse system, academic system, and social science system. For such course content, laws and regulations related to their profession can be introduced in a timely manner. In the process of guiding students to observe social practice, teachers should enhance their professional qualities such as moral and legal qualities, integrity, and benefiting the people.

Second, in the process of students learning engineering, scientific and other professional courses, teachers should efficiently integrate the relevant scientific spirit of the major and Marxist ideas, to improve the 
students' ability to discover and solve problems. For scientific courses, university teachers should adopt appropriate teaching methods to cultivate students' scientific ethics education and scientific thinking mode, and gradually cultivate their sense of mission and responsibility to pursue truth and to explore the unknown in daily teaching. In the process of learning such professional courses, it is necessary to promptly strengthen the students' own engineering ethics education, improve their work spirit, make them carry the special mission of "Great Power Craftsman," and inspire their feelings of mission of serving the country with science and technology. Therefore, in the daily teaching of science and engineering universities, teachers should integrate appropriate ideological and political idea within curriculum with professional curriculum, so as to effectively enhance students' professional standards and mission awareness.

\subsection{STRENGTHENING THE CURRICULUM'S IDEOLOGICAL AND POLITICAL CONSTRUCTION}

In the process of constructing ideological and political idea within curriculum, curriculum designers of science and engineering colleges and universities should place ideological and political idea within curriculum in the teaching of professional curriculum. For example, ideological and political idea within curriculum can be placed in the compilation of syllabus, teaching plans, course goals, and textbooks, and then penetrated into the homework essays, experimental training, teaching seminars, and classroom teaching. The key content in the textbooks should be integrated with the ideological and political idea within curriculum to set up more appropriate cultivating plans for talents.

During the period of innovative classroom teaching mode, the majority of teachers should use network information to teach ideological and political idea within curriculum, mobilizing students' learning interest and making them thinking more in-depth. University administrators can also timely develop a management system that combines classroom teaching and ideological and political idea within curriculum, scientifically manage the classroom teaching, and comprehensively improve the level of integration of the related ideas and classroom teaching. In addition, teachers also need to flexibly use the second classroom and the first classroom in daily teaching, organize a number of ideological and political lectures through the rationality of the internal management system, and provide more practical services, such as "Red Dream Building Journey", voluntary service and social practice, accurately finding out the current curriculum's ideological and political construction methods, and comprehensively enhancing students' understanding of ideological and political idea within curriculum.

\subsection{IMPROVING TEACHERS' IDEOLOGICAL AND POLITICAL STANDARDS}

In the process of helping students expand their ideological and political idea within curriculum, the ideological ideas of teachers in science and engineering universities are more important. Therefore, when comprehensively promoting curriculum's ideological and political construction, teachers at all levels should enhance their own educational ability, recognize educational perspectives and improve educational awareness. During the construction of the curriculum's ideological and political education system, colleges and universities should build a curriculum's ideological and political exchange platform that conforms to their own development ideas in a timely manner, and place appropriate ideological and political idea within curriculum and the main content integrated with related professional courses on the network platform. Platform is to enhance the sharing effect of this idea, and build a mechanism for sharing high-quality resources in a timely manner ${ }^{[4]}$. Regarding the exchange platforms under the ideological and political idea within curriculum of multiple universities, based on the differences of the disciplines of different universities, in the current science and engineering universities, relevant personnel will complete the knowledge design according to different disciplines and different fields. During the design period, they will also have close conversations with university administrators and teachers to fully understand their current thinking, so that the designs can be in line with the universities' development directions. In addition, colleges and universities can also hold a number of activities related to the curriculum's ideological and political theory in daily life, such as teacher training, exchange of typical experiences and on-site teaching observations, as well as take the advantage of modern information to complete the knowledge distribution of various teaching resources among university sharing platforms.

\subsection{ESTABLISHING A CURRICULUM'S IDEOLOGICAL AND POLITICAL EVALUATION SYSTEM}

In order to promote the effect of talent cultivating in science and engineering colleges and universities, after completing the construction of the ideological and political idea within curriculum system, the colleges and universities should also establish a curriculum's ideological and political evaluation system in a timely manner. Specifically, in the process of constructing the ideological and political idea within curriculum, the primary criterion for judging its effect is the quantity and quality of talent cultivating. It is extremely necessary to establish a multi-angle curriculum's ideological and political evaluation system. In the inspection and evaluation of ideological and political idea 
within curriculum, each university can effectively implement various curriculum's ideological and political management policies, and university administrators can establish professional degree guidance exchange meetings, various discipline steering committees, and discipline review groups, to make the evaluation criteria of ideological and political idea within curriculum more diversified, thus effectively strengthen the evaluation effects of various majors in the universities. During the construction of the curriculum's ideological and political evaluation system, university administrators should strictly implement the basic content of their own policies, use the system to strictly observe the students' mastery of various professional knowledge and ideological and political idea within curriculum, and raise the standards up to the important position within the system, making a deeper integration between the curriculum system and ideological and political idea. In the process of teachers participating in the curriculum's ideological and political evaluation system, the administrators should combine the teachers' teaching effects with training, evaluation, rewards, recruitment and assessment, and therefore make the evaluation more scientific and rational.

\section{CONCLUSION}

In conclusion, in the process of constructing ideological and political idea within curriculum, the leaders of science and engineering colleges and universities need to confirm the systematicness of work, that is, using appropriate top-level design to optimize the ideological and political idea within curriculum and professional knowledge, and using the corresponding characteristics of different courses and majors to improve the guidance effect of ideological and political idea within curriculum, to enhance the comprehensive quality of students in such colleges and universities.

\section{[PROFILE OF THE AUTHOR]}

Peng Zhang, January 1988, male, Han nationality, from Changge, Henan province, $\mathrm{PhD}$ student, lecturer, engaged in research on international relations.

\section{ACKNOWLEDGMENTS}

[KEY PROJECTS ${ }^{1}$ ] Research on the evolution of the ASEAN and AU institution (SK2020A0198), a key project of the Humanities and Social Science Research Project of Anhui Province Colleges and Universities; This paper is subsidized by Anhui University of Science \& Technology's introduction of talents research start-up fund "ASEAN, AU institution evolution research" (Program Number: 13200382)

[KEY PROJECTS $\left.{ }^{2}\right]$ This paper was supported by the Key Project of Scientific Research Fund for Young Teachers of Anhui University of Science and Technology in 2020 《Research on the Role of Emotional Experience in Virtual Reality Animation 》.(Program Number: QNSK202002)；

\section{REFERENCES}

[1] Liu Xingping, Zhang Dapeng. Analysis of Ideological and Political Elements in the Courses of Science and Engineering[J]. Journal of Mianyang Normal University, 2021, 40(06): 23-27.

[2] Meng Haiping, Lin Xinyan, Qin Bendong. Analysis of the Path of Ideological and Political Practice in Science and Engineering Courses[J]. Educational Exploration, 2021(05): 66-69.

[3] Pan Meng, Li Xingyang, Li Fang. The Role of Ideological and Political Education in Core Courses of Science and Engineering Majors[J]. Education Science \& Culture Magazine (First ten-day issue), 2021(05):81-82+109.

[4] Guan Beibei, Yuan Ding. Inquiry into the Construction of Ideological and Political Courses for the Cultivation of Humanistic Quality in Science and Engineering Universities[J]. Journal of Higher Education, 2021, 7(13): 25-28. 